Peer review: This article has been subject to a double blind peer review process

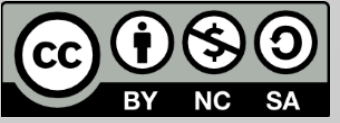

(C) Copyright: The Authors. This article is issued under the terms of the Creative Commons Attribution NonCommercial Share Alike License, which permits use and redistribution of the work provided that the original author and source are credited, the work is not used for commercial purposes and that any derivative works are made available under the same license terms.

\section{Participatory Development: A Tool of Pedagogy}

\author{
Akor Omachile Opaluwah * \\ Nottingham Trent University \\ *Correspondence: omachile@yahoo.com
}

\begin{abstract}
Participatory development has been heralded as a tool capable of bringing development to the most marginalised people. Theorists including Robert Chambers, Mohan Giles, Kristian Stokke, Paulo Freire and Amartya Sen have argued extensively on the importance of including people in the decisions that affect their livelihood. One of the benefits of a participatory approach to development is in its pedagogical capacity; especially in teaching people about institutional structures and civic engagement. To harness this capacity of participatory development, participation must be viewed as an end of its own. This article is an investigation into this pedagogical capacity of participatory development. It focuses on participation in non-physical activities such as participatory budgeting and participatory policy making. This is in order to understand its effect on the capacity of citizens to understand and engage with social structures which affect their livelihood. Understanding this capacity of participatory development to increase the level of civic engagement between citizens and their society, is needed for better development planning. Thus, the conclusion highlights the potential for participation to increase citizen engagement with the structures in society. Again, it is with such understanding, that participatory projects and processes can be designed to produce benefits that transcend the lifeline of the project.
\end{abstract}

Keywords: Participatory development, pedagogy, citizen, participation, Participation, Tostan

\section{Introduction}

Participatory development, since the 1970 s, has been an approach to development that has gained gradual momentum due to its far-reaching coverage. Participatory development, unlike older development theories that relied on a top-down approach, was finally able to reach the poor and marginalised effectively. The emergence of the theory (and practice) of participatory development has occurred against the backdrop of a 
critique on development which viewed development as having a propensity to be biased and also disempowering (Mohan, 2001).

Development theories of the 50s and most of the 60 s focused primarily on economic growth. The notion that a strong economy is the basic ingredient needed for the attainment of development was a central focus for such theories. These biases, Chamber (1997) and Escobar (1995) argued include the top-down perception of development, positivism, and Eurocentrism. 'The overarching tendency is to equate development with 'modernity' which means the modernity as achieved by 'western' societies' (Schuurman, cited in Mohan, 2001:1).

Unfortunately, these arguments for top-down development had produced limited results. With many developing countries making very little progress and some on the verge of bankruptcy, the rise of alternate arguments emerged. Thinkers like Freire (1970) argued that people needed to participate in development planning and processes. He noted that people needed an enabling environment where they could express their needs and achieve development themselves. Chambers (1983), in his book, Putting the Last First, argued extensively that unless participation was rooted in our development practice, sustained development would be impossible. Consequently, this era saw the rise of the participatory approach to development.

\section{Participatory Development}

Participatory development just like many other terms in the field of social science is plagued with a multitude of definitions. Some of which will be explored in this section.

Participation as defined by the German agency, GTZ is, 'co-determination and power sharing throughout the...programme cycle' (cited in Nelson and Wright, 1995: 4). This definition looks at participation as the cooperation between the local agents and external agents working on a project. Participatory development is also defined by the Asian Development Bank (1996) as the 'process through which stakeholders can influence and share control over development initiatives, and over the decisions and resources that affect themselves.' Also, participation according to Begadon (1990) is the sharing of tasks and responsibilities in the planning, construction and management of a project.

ljaiya argues that 'participation is a means of acquiring new rights and a form of social action that is voluntary, rational and based on the benefit that individuals (or communities) have which allows for co-operative solutions' (2006:2). He further notes that "it is an instrument for 
negotiating divergent interests". Participatory development, he notes, does not eliminate losses but rather, it makes these losses transparent and acceptable".

The definition of participation by the World Conference on Agrarian Reform and Rural Development has influenced many development agencies in their approach to participation. This view argues that:

Participation by the people in the institutions and systems which govern their lives is a basic human right and also essential for realignment of political power in favour of disadvantaged groups and for social and economic development. Rural development strategies can realise their full potential only through the motivation, active involvement and organisation at the grass-roots level of rural people, with special emphasis on the least advantaged, in conceptualising and designing policies and programmes and in creating administrative, social and economic institutions, including co-operative and other voluntary forms of organisation for implementing and evaluating them. (cited in Mohan, 2006:11)

This definition sees the transfer of power as an implicit part of participation. This view (as compared to the view of participation as an informative tool, participation as a means or participation as a project specific activity) has continually gained ground over the past decade (Oakley, 1995). Not only do proponents of this perspective on participation argue that it brings people into the process of development, it is further argued to be a basic human right.

Duraiappah, Roddy and Parry (2005: 5) note that 'at its pinnacle, participation involves a transformation of the traditional development approach towards the enhancement of the capabilities of the local people and communities to define and address their own needs and aspirations'. This view of participation, along with Gran (1983), Chambers $(1983,1997)$ and further works of Sen (1999) emphasise the need of people to be actively involved in the process, with a focus being placed on the capability of the people.

Mohan (2001) stresses that participation in its most fundamental form is concerned with power relations (Mayo and Craig, 1995: 5-6; Nelson and Wright, 1995: 7-11). This power struggle he argues, is sometimes violent as the less powerful must at times, struggle with the powerful, for an increased level of control over their lives. Bush (2007) corroborates this as he argues that poverty and underdevelopment as an unequal power relation. Nonetheless, participation involves giving a voice to the (formerly) voiceless, so they can influence the factors or decisions that affect their livelihood. Sen (1999) takes it a step further and defines 
development as the process of expanding the substantive freedom people enjoy. From that definition, we can say participatory development is the expansion of substantive freedom by the very group of people in need of this freedom.

All these literatures on participation talk about the consequences of participation in terms external to the participant. These views see participation as a benefit to the people with regards to what they can do with opportunity to participate, or what they can get when they participate. This dichotomy of participation as a form of empowerment, or as a means to economic growth both possess the same flaw - which is viewing participation and its effect as external to the individual. This article focuses firstly on the approach of participation as empowerment. Primarily, this view sees the fundamental benefit of participation as a shift of "power" from a fixed and non-inclusive leadership system to a more decentralised form of governance. This empowerment approach argues that participation will bring this power shift to the formerly ostracised/marginalised members of society.

Though there is still exhaustive discourse on both sides of the argument (participation as an end and participation as a means), there is relatively less insight given on the effect of participation on the participants. Writers like Dewey acknowledge that there is a degree of change that occurs in the participants. This educational/pedagogical effect of participation is argued to occur due to factors that occur during the process of participation. These include:

1. The proximity to the operations (or creation) of the institutions that determine their livelihood

2. The availability to and exposure of participants to new knowledge and information

3. The establishment and growth of social connections

4. The serendipitous nature of discourse and debate

Many writers differ in their views on participation. These different views of participatory development and the approaches taken to incorporate it in development practices have varied over time, and is continually being debated. Mansuri and Rao (2013) note that even though the practice of participatory development has been around for over three decades, there is still little known as to why or how to make people participate. Though many questions and doubts about our knowledge of how participation works, there is evidence exhibiting of its effects. For such to be improved, there needs to be further investigation into how 
participation affects the individual. To do that the concept of empowerment needs to be explored.

\section{Empowerment}

Empowerment is the 'process of enhancing an individual's or group's capacity to make and express choices and to transform them into desired actions and outcomes' (Gibson and Woolcock, 2005: 1). Empowerment is also defined as 'the expansion of assets and capabilities of poor people to participate in, negotiate with, influence, control, and hold accountable institutions that affect their lives' (Narayan, 2002: 14).

Servaes defines empowerment as 'making sure that people are able to help themselves' (1999: 194). More broadly, Melkote and Steeves (2001:37) define empowerment as 'a process in which individuals and organisations gain control and mastery over social-economic conditions, over democratic participation in their communities and over their own stories'.

The concept of empowerment lies closely with the perception of underdevelopment as a product of flawed power relations. When the decision-making power lies far from the locality where its effect is most felt, and the members of such communities are unable to influence these decisions, there is a high propensity for marginalisation and unfreedom. Even when it is noted that the local populations are invited into the development discourse, Bush (2007) notes that their flawed inclusion in the system results in more poverty and underdevelopment.

Gran argues that;

to get poor people effectively involved, this entire up-front blueprint approach to social engineering will have to be drastically modified in the direction of process planning. Part of the development must be the empowerment of the people to do their own planning. If they are not ready to plan, they are not ready for a complicated interaction with an outside agency. (1983: 242)

Gran argues for the inclusion of people in the development process. He sees their involvement as a sign of their readiness to partake in the complicated process of development. This complicated process which he refers to is the process of conceptualisation, problematization, planning, monitoring and evaluation and re-planning. The involvement of people in the development process he notes, will bring about a reversal of the biases which have marginalised and alienated the poor. Chambers (1983) noted some of these biases such as project bias, person bias, seasonal 
bias, diplomatic bias and professional bias have repeatedly led to the selection of projects that lie far from the priorities of the locals.

From Sen's definition, development that involves the removal of the 'unfreedoms' that people suffer is substantive, and the only way that these can be addressed effectively is by including these people in plans and practices that are designed to bring about this freedom. These unfreedoms he listed are poverty, tyranny, poor economic opportunities, systematic deprivation, lack of public facilities, intolerance and overactive or repressive states. Their inclusion, Sen further emphasises is not just the seeking of their opinions on projects, but the increase of their capacity to attend to the matters the face, themselves.

Bush (2007) defining poverty as a power relation argues that this uneven integration of people into the world economic system is the reason for the persistence of poverty. He also argues for the total inclusion of people in the process of development. He then presses on to note that the partial or misguided inclusion of people in the development agenda can perpetuate even more poverty and underdevelopment. Bush (2007) sees development and participation as an approach to dismantling the structural forces that have prolonged poverty and underdevelopment in human society.

Getting people to participate has come to represent a major way of thinking about development. Rahnema (1992) though warns that participation stands the risk of being abused due to the ease with which governments have accepted it. He notes is a result of the fact that the concept of participation is no longer seen as a threat. The implementation of a participatory project or the use of a participatory approach to a project is determined by the perception people have about participation. This is the view of participation as either a means or as an end.

\section{Participation as an end and as a means}

Two decisive ways in which the concept of participation can be viewed are as a means or participation as an end. Brohman (1996) notes that the distinction between participation as an 'end' or as a 'means' completely influences the way a project will be implemented. The notion of this willingness to empower the marginalised can be inferred from the perception of participation held. Schneider and Libercier (1995a) note that there are definitely very distinct notions of participation in the development discourse. However, genuine participation must always include some form of empowerment. 
Participation viewed as a means implies teamwork. In this approach, participants are primarily brought together for the purpose of collaborating to achieve a defined goal. Their contribution is utilised primarily to facilitate the success of the project. ILO (1995: 3) in analysing the Kalerwe community-based drainage upgrading project in Uganda, noted that the inclusion of participants ensured the structure created by including participants in the project would be maintained by the people themselves even after the project had been completed. When participation is viewed as a means in projects, it has been found to increase the efficiency and the sustainability of projects.

Tufte and Mefalopulos (2009) argue that viewing participation as a means does not constitute any serious form of empowerment. This is because the primary beneficiaries are not instrumental in the decisionmaking process. Rather they, as participants, are viewed as tools that will bring about the success of the project. Parfitt notes that when participation is viewed as a means, it 'is indicative that power relations between those at the grass roots, or the target community, and the aid/governmental agencies, will be left largely untouched' (2004: 539). The process of conceiving and planning of the project is left mainly with the traditional authorities while the role of the mobilised participants is to rally around and work on these predefined goals.

Participation viewed as a means illustrates the concept of participation as collaboration. This perspective is often seen as the way by which a NonGovernmental Organisation (NGO) or the Governments can call upon stakeholders in the form of local people's labour, knowledge and skills in the implementation of rural development policy. This view of participation leans on the notion that the only benefit that people can get from participating in a project is the successful completion of the said project. If there is an unfortunate failure of the project, then this will culminate into a total waste of time and resources. The process is deemed participatory because the completed project is primarily for the benefit of the participants as opposed to the use of foreign workers.

The extended effect of this can be seen in the way such a program is designed. In such a participatory process, the participants will have a relatively passive role. This culminates in the little or no relinquishing of power in the process.

It is based on this notion that Rahnema (1992) argued that over time, governments and organisations would warm up to this version of participation (as a means) where the participants' involvement would be minimal, and there will be little or no relinquishing of power by the elite. Participation is, in this way, seen as an instrument for achieving development objectives; participation is a politically attractive slogan. 
The other perspective; participation as an end, places the participatory process as a core objective of the entire narrative. When participation is understood as an end in itself, the project objectives become directed towards the increase of the capacity of the participants. This increased capacity is perceived as instrumental to them being able to solve the problems they encounter, and improve their living and working conditions themselves. ILO note that 'participation as an end is based on the assumption that every country and every target group bears the primary responsibility for its own development. In this sense, participation is guided by the principle of self-reliance' (1995: 3). Oakley notes that participation as an end, 'is a broader concept and more linked to breaking down existing barriers and constraints - political, social and psychological - to people's participation' (1995: 6). This stems from the implication that participation when viewed as an end constitute empowerment and power change.

In participation as an end, the emphasis is placed on the process over the physical product of the practice. Nikkhah and Redzuan corroborating Asnarulkhadi (1996) defined it as a process in which people are directly involved in shaping, deciding, and taking part in the development process from the bottom-up perspective' (2009:173). Agreeing with Moser (1989) and Richardson (1983), they further note that in participation as an end, 'the development goal is of secondary importance, but the process whose outcome is an increasingly meaningful participation in the development process, direct participation, or active participation from people emerges where their confidence and competence are built up. In this situation, participation becomes a process of achieving greater individual fulfilment, personal development, self-awareness and some immediate satisfaction' (Nikkhah and Redzuan, 2009: 173).

For participation to lead to empowerment, there must be a consciousness as to its usage not being only as a means but as an end. An end as such will be the increase of the capacity of the participants to address the constraints they face in their society.

Empowerment as a participatory development approach has an ultimate goal of raising the capacity of the participants. This goes beyond only granting them infrastructure or physical resources. The process of participation increases the mental capability of participants to actively challenge the status quo or at least contemplate the system within which they reside. This is the pedagogical effect of participation. This inherent ability of participation that develops in people the capacity for selfreliance and the ability to affect their livelihood consciously, is due to this pedagogical nature of participation. 


\section{Pedagogy}

Pedagogy, defined by Watkins and Mortimer is 'any conscious activity by one person designed to enhance the learning of another' (1999: 3). Alexander defines pedagogy as 'the act of teaching together with its attendant discourse. It is what one needs to know, and the skills one needs to command in order to make and justify the many different kinds of decisions of which teaching is constituted' (2003: 3).

Leach and Moon define pedagogy as 'the practice that a teacher, together with a particular group of learners creates, enacts and experiences' (1999: 267). This definition suggests that pedagogy, is not a one-sided activity. Rather, it involves the teachers and the students, thereby drawing on the strengths of social interaction. This social interaction that Leach and Moon emphasise, is responsible for the sharing of knowledge in a given discourse.

The factors that enhance pedagogy are numerous (Bruner, 1999; Loveless, 2002). The increased attention the art of pedagogy has garnered in recent years has emphasised the importance it bears not only in the educational sector but in other key areas like participation and development. Of particular importance is the role these participants play in the development of the process that they learn from. Freire argues that people ought to be amongst the developers of the pedagogy that they learn from. This he further argues by stating that 'no pedagogy which is truly liberating can remain distant from the oppressed by treating them as unfortunates and by presenting for their emulation, models from among the oppressors. The oppressed must be their own example in the struggle for their redemption' (1972: 30).

Freire's submission on the role participants need to play in pedagogy draws a parallel with the role Gran (1983) advocates needs to be played by people. That learners are not merely participants with the hopes of gaining something from the 'experts', but they are, in their own rights, possessors and hence contributors of knowledge.

Likewise, the teachers (or experts) are not only instructors, with nothing to learn from the participants, but also students as they do not possess the totality of knowledge. Chambers (1983) does caution about the tendency for participants or facilitators (teachers) to swing to the other extreme of the pendulum where the participants think their knowledge is superior and the experts think that their knowledge is inferior. Just like Ricoeur admonishes on hermeneutics and language, there needs to be a respect of one's and other's knowledge. 


\section{Pedagogy and participation}

In analysing the definitions of pedagogy, it is possible to see the role of the students in learning. The passage of knowledge is not a unidirectional activity, rather, learning should be a form of knowledge discovery, experienced by all parties involved. This multi-directional form of learning, as discussed by Chambers (1983) involves is present in participation. 'When citizens become involved in working out a mutually acceptable solution to a project or problem that affects their community and their personal lives, they mature into responsible democratic citizens and reaffirm democracy' (Webler, Kastenholz, and Renn, 1995: 2). This communal way of learning can be described as social learning.

Social learning as defined by Bandura (1977) is defined as individual learning that occurs in a social context and therefore is influenced by social norms. Examples of such is the imitation of role models and the learning a language by cultural integration. This definition, as argued by Reed et al. (2010), broad and encompasses every form of learning, since every form of learning occurs with one form of social context or the other. Reed et al writing on social learning emphasise that

Learning essentially occurs in an individual through some form of change in a persons' understanding of the world and their relationship to it. However, the process of learning in individuals most often occurs through social interaction with others and/or facilitative mechanisms such as dissemination of information. More than one person can, therefore, learn as an emergent property of the reinforcing interactions between people, through networks. The learning that takes place can be at surface levels or involve deeper conceptual change, and can occur at group, community, or societal scales. (2010: 3)

It is one thing to understand the effect of social learning that occurs to participation in development projects, it is another to understand the mechanism by which this learning occurs within the individual. PahlWostl (2006) and Kuper et al. (2009) note that many attempts at assessing social learning and participatory development have failed to disentangle the effects of the intervention/participation from the mechanisms through which the learning (or the pedagogical effects) occur. If participation as empowerment, is the emphasis of a development project, then the effectiveness of the process depends on the understanding of how to enhance the capacity of the participants. In other words, understanding the way participation learn, will increase the chances of success of the project. 
Dewey (1916) emphasised that knowledge can be passed by relating instructional content to students' experience thereby allowing them to combine their experiences with the information made available. In other words, the more people can relate to a way of thinking or a piece of information, the more likely they are to learn and adopt that. On the same note Cummins, Brown \& Sayers (2007) corroborate the theories of Vygotsky (1987) argues that the construction of knowledge is best achieved via social interaction (i.e. social learning). They further argue that the capacity of students to actively inquiry, and the social construction of knowledge are seen as more important to increasing the effectiveness of the process of learning than simple transmission of information.

Their perspective is in line with the social constructivist view of pedagogy. 'The social constructivist goal of enabling students to build knowledge and develop deeper levels of understanding frequently requires dialogue and collaborative inquiry rather than just memorisation and practice' (Cummins, Brown and Sayers, 2007: 38).

In development, this dialogue is most emphasised in participation; particularly as an end, or as Ditcher (1992) refers to it, as the basis for development. In participation as a means, participants are usually relegated to the sidelines as their contribution is only in the form of surveys or (in some cases) physical tasks. There is minimal dialogue or intellectual interaction. It can be argued that such participation teaches physical skills to the participant which are likely to transcend the lifetime of the project. Though this is true, there is usually a trace amount of empowerment involved. Just as Rahnema warned, participation of this nature becomes attractive to governments and large organisation due to the reduced chance of the shift in the status quo. This he argues is because there is little or no empowerment of the participants. There is not any transferred power or autonomy, and neither are the participants capable of proffering solutions based on their involvement. UNDP (2004) notes that when participatory programs are designed with empowerment as a central aim, it inevitably imbibes in the participants, the capacity to organise. It also provides them with an environment that facilitates learning while participating.

It is through this form of participation, where empowerment is a major goal that the participants can learn to define their goals and objectives assess the implications of available options critically, and also grow to be responsible for their actions and inaction. Freire (1970), argues for this in his defence of social learning where he notes that though social learning, it is possible for people to become critically literate about their 
circumstances, thereby achieving 'consciencialização' (critical consciousness) through collective reflection and problematising.

Waddington and Mohan (2004) insist that empowerment gained from participation and its inherent efficacy for social learning, is raising institutional capacities, allegiance building, development of identities and confidence in the participants. It, therefore, is because of the capability of such participatory avenues, that the participants gain a better understanding of the systems in which they live in, understand their roles and growing capabilities, and tend to engage in it for their benefit. Freire (1970) advocated for the engagement of people through free, open and continuous dialogue. In this, he argued that it would give room for the people to deliberate and reflect on their problems, thereby asking questions and achieving solutions.

The essence of dialogue to participation and development as a whole, is the provision of a broader view of an issue to the participants involved in the dialogue, while also providing them with as many perspectives as there are participants. Hence, in the proper engagement of the participants, they would share idea and knowledge, and furthermore challenge the situation they face with a wide range of approaches. ElGack argues that the 'local poor need to be genuinely empowered if alternative development strategies are to achieve their objectives' (2007: 25). It is this process of engagement that proffers this avenue for discourse. Gran notes that 'Participatory development implies openended egalitarian learning, not hierarchical, authoritarian learning' (1983: 238).

Advocating the social constructivist approach, Gran (1983) corroborating Vygotsky (1978) sees participatory development as an avenue that fosters learning, not only amongst the locals but also with the facilitators. Much of this approach has been used by Tostan in their educational programs in West Africa. Their curriculum has been described as culturally based and learners centred (Fredo, 1995; Welch, 1995: 266273, Gillespie and Melching, 2010). The involvement of learners in building the curriculum has been noted to be a rudimentary requirement for understanding Tostan's turn to democracy and human right (Easton, Monkman and Miles, 2003; Mackie, 2000; Melching, 2002). This also led to the successes they have encountered as an organisation in addressing the issue of Female Genital Cutting (FGC).

Tostan has always engaged learners to determine how and what they learn. Though time-consuming, their approach has allowed the participants to contribute to the curriculum and therefore, direct the trajectory of their learning. This has invariably put the participants at the centre of determining what the Tostan program will bring to their 
community. Gillespie and Melching note that 'They refined a pedagogical approach in dialogue with participants and experimented with integrating African cultural practices, such as singing, storytelling, and performing, and pedagogical strategies, such as consensus building and mediation, with information on health care, as they had done for the radio programs' (2010: 484). In the Tostan model of education, there are no teachers or students, rather there are facilitators and participants. The curriculum was thus saturated with the experiences that each participant had experienced, rather than storied that were external to them.

McLoughlin and Lee note that the challenge for development planners as well 'is to enable self-direction, knowledge building, and learner control by providing options and choice while still supplying the necessary structure and scaffolding' (2008: 17). An understanding of these structures, the mechanisms and conditions that facilitate learning is essential in the design of participatory programs. If these conditions are effectively implemented, pedagogy will be effective and beneficial to the participants. These conditions which include, engaging prior understanding, integrating factual knowledge with conceptual frameworks, and taking active control over the learning process, at necessary pre-conditions for any form of participatory development planning. Donovan and Bransford emphasis that 'new understandings are constructed on a foundation of existing understandings and experiences' (2005: 4). They argue that the possession of foundational knowledge is a prerequisite for new learning. One advantage social learning holds is that conditions which are for the effectiveness of participatory development program planning, already exist in abundance with the participants. These foundations, therefore, do not need to be laid again. Rather, the process of learning will be able to work based on the already establishes knowledge of the group of participants.

Cummins, Brown and Sayers note that 'prior knowledge, skills, beliefs, and concepts significantly influence what learners notice about their environment and how they organise and interpret it' (2007: 42). Evident in the Tostan practice, is the fact that the curriculum presented is only in a skeletal form. It is the stories and experiences of the participants that complete the curriculum. Facilitators had built on the knowledge and social networks already possessed by the participants.

\section{Benefits of pedagogy to participation}

When citizens are informed in development projects and policy process, they become citizen experts, understanding technically difficult situations 
and seeing holistic community-wide solutions. The more participation occurs with a more sophisticated level of technical and social understanding, the higher the chances of yielding better policy decisions and thus better social and environmental outcomes (Irvin and Stansbury, 2004). This process of being better informed can be attained through participation, as the participants will be in the middle of deliberations that will eventually lead to policies. Barnes (1999: 67) notes that a key objective of participation is to create a healthy and more active democracy. One which caters for all members of the society. This process of creating this democracy is dependent on the level of education of the citizens, and their understanding of the system (and society) in which they live. The knowledge gained while participating, increases the potential and capacity of the participant to, in further participatory programs, be more effective. It thereby feeds into the system, the factors necessary for a stronger democracy.

Elections and voting, being a basic form of participation is preceded by citizens making conscious efforts to educate themselves on the political parties, candidates, policies and ideals. This process tends to increase the capacity of the citizens. Michels, A. and L. De Graaf (2010: 480) note that 'citizens may increase their civic skills and become more competent if they participate in public decision-making'. This act of participation by citizens places the citizen in the public sphere. In this arena, they are open to their civic duties and thus the skills for them are learned.

\section{Conclusion}

Learning may occur in the participants at different levels. This, unfortunately, does not always lead to a change in attitude due to a plethora of reasons as shown by Ison et al. (2007) and Stagl (2007). Therefore, it will be erroneous to postulate that participation automatically leads to learning which leads to social change. The evidence does show that the propensity for social learning is increased during participation, as the factors that could encourage such learning are present (information, participants). It is logical to conclude, therefore, that if orchestrated or managed effectively, rather than left to chance, this learning can be made more effective.

Duraiappah, Roddy and Parry note that 'there is no doubt that the introduction of participatory approaches to development over the past three decades has effectively demonstrated the capacity of men and women from poor communities to participate actively in research, project design and policy analysis. Experience with these methods has also demonstrated that the manner in which these individuals are 
included in a process sets the context for the results ultimately generated' (2005: 27). It, therefore, is essential for governments, NGOs, facilitators and development experts to be conversant with the various mechanisms of pedagogy and social learning, their benefits and challenge. This should then lead to the implementation of participatory programs designed around the capacity of the participants to learn. In this form of participatory development planning where the mechanisms of social learning and pedagogy are understood, the design of a participatory program geared towards the empowerment of participants will be intentional and hence, hold more chances of success.

\section{Abbreviations}

FGC - Female Genital Cutting

GTZ - German Technical Cooperation Agency

UNDP - United Nations Development Program

WCARRD - World Conference on Agrarian Reform and Rural Development 


\section{References}

Asian Development Bank (ADB). (1996). Framework for Mainstreaming Participatory Development Processes into Bank Operations. Manila.

Bandura, A. (1977). Social learning theory. Prentice Hall, Englewood Cliffs, New Jersey, USA.

Banks, F., J. Leach. and B. Moon, (1999), 'New understandings of teachers' pedagogic knowledge', Learners and pedagogy, 2(8), 89-110.

Barnes, M. (1999), 'Researching public participation', Local Government Studies, 25(4), 60-75.

Black, P., and D. Wiliam. (1998), 'Assessment and classroom learning', Assessment in Education, 5(1), 7-74.

Blackburn, J.W. and W.M. Bruce. (1995). Mediating environmental conflicts: Theory and practice. Greenwood Publishing Group.

Botes, L. and D. van Rensburg (2000). 'Community participation in development: nine plagues and twelve commandments', Community Development Journal, 35 (1), 41-58.

Bransford, J.D., Brown, A. and Cocking, R. (2000). How people learn: Mind, brain, experience and school, expanded edition. DC: National Academy Press, Washington.

Brohman, J. (1996). 'Popular development: Rethinking the theory and practice of development'. Wiley-Blackwell.

Bruner, J. (1999). 'Folk pedagogies'. Learners and pedagogy, 1(1), 4-20.

Chambers, R. (1997), 'Whose Reality Counts? Putting the first last', Intermediate Technology Publications, London.

Chambers, R. (1983), 'Rural Development: Putting the last first', Longman, Harlow.

Cummins, J., K. Brown and D. Sayers (2007). 'Literacy, technology, and diversity: teaching success in changing times', Boston M.A. Pearson, Allyn \& Bacon.

Dewey, J. (1916). Democracy and Education: An Introduction to Philosophy of Education. Macmillan.

Ditcher, T. (1992), Demystifying popular participation. Washinton DC: World Bank.

Donovan, M.S. and J.D. Bransford (ed.) (2005). How students learn: History in the classroom, National Academies Press. 
Dreze. J and A. Sen, 1990 (Ed.), The Political Economy of Hunger, 3 Vols, Oxford, Clarendon Press.

Duraiappah, A. K., P. Roddy, and J.E. Parry (2005). Have participatory approaches increased capabilities? International Institute for Sustainable Development $=$ Institute international du développement durable. Minitoba, IISD.

Easton, P., K. Monkman, and R. Miles (2003). 'Social policy from the bottom up: Abandoning FGC in sub-Saharan African', Development in Practice, 13 (5), 445-458.

Escobar, A. (1995) Encountering Development: the making and unmaking of the Third World, Princeton University Press, Princeton.

Fazey, J. A., and F. Marton (2002). 'Understanding the space of experiential variation', Active Learning in Higher Education, 3 (3), 234250.

Fredo, D. A. (1995). 'Women's literacy, indigenous form and authentic colearning: A research approach to participatory training for national language literacy in rural Senegal'. Unpublished doctoral dissertation. University of Massachusetts, Amherst.

Freire, P. (1972). Pedagogy of the Oppressed. London and New York: Penguin Books.

Gibson, C., and M. Woolcock (2005), 'Empowerment and Local Level Conflict Mediation in the Kecamatan Development Project in Indonesia: Concepts, Measures and Project Efficacy', Policy Research Working Paper 3292, World Bank, Washington, DC.

Gilbert, A. and P. Ward (1984). 'Community action by the urban poor: democratic involvement, community self-help or a means of social control?', World Development, 12(8), 769-782.

Gillespie, D., and M. Melching (2010). 'The transformative power of democracy and human rights in non-formal education: The case of Tostan', Adult Education Quarterly, 60(5), 477-498.

Gran, G. (1983). Development by people: Citizen construction of a just world. Praeger Publishers, New York.

GTZ (1991). Where There is no Participation, Eschborn: Deutsche Gessellschaft fur Technische Zusammenarbeit.

Ijaiya, T.G, (20060, 'Participatory Development and Project Performance in Nigeria: An Assessment of the existing DFRRI Borehole Water Projects in Offa, Kwara State', Geo-Studies Forum, 3(1-2), 145-155 
International Labour Organisation (ILO) (1995). 'Participation and tripartism in the ILO's Mandate', a publication of the 264th session of the Governing Body. GB 264/TC/2.

http://www.ilo.org/public/english/standards/relm/gb/docs/gb264/tc2.htm, accessed 15 December 2015.

Irvin, R. A., and J. Stansbury (2004). 'Citizen participation in decision making: is it worth the effort?', Public administration review, 64(1), 5565.

Ison, R., and D. Watson (2007). 'Illuminating the possibilities for social learning in the management of Scotland's water', Ecology and Society 12(1): 21, http://www.ecologyandsociety.org/vol12/iss1/art21/, accessed 19 June 2016.

Kuper, M., M. Dionnet, A. Hammani, Y. Bekkar, P. Garin, and B. Bluemling (2009), 'Supporting the shift from state water to community water: lessons from a social learning approach to designing joint irrigation projects in Morocco', Ecology and Society 14(1), 19, http://www.ecologyandso ciety.org/vol14/iss1/art19/, accessed 19 June 2016.

Loveless, A. (2002), 'Literature review in creativity, new technologies and learning', Journal of Distance Education, 4, 11.

McLoughlin, C., and M.J. Lee (2008), 'The Three P's of Pedagogy for the Networked Society: Personalization, Participation, and Productivity', International Journal of Teaching and Learning in Higher Education, 20(1), 10-27.

Melching, M. (2002). 'Abandoning female genital cutting in Africa', in S. Perry \& C. Schenck (ed.), Eye to eye: Women practicing development across cultures, New York: Zed Books, pp. 156-170.

Mohan, Giles (2001). 'Participatory development', in Desai. V and R. Potter (ed.), The Arnold companion to development studies. London, UK: Hodder, pp. 49-54.

Mayo M \& Craig G (ed.) (1995), Community Empowerment: A Reader in Participation and Development, London: Zed Books.

Michels, A. and L. De Graaf (2010), 'Examining Citizen Participation: Local Participatory Policy Making and Democracy', Local Government Studies, 36(4), 477-491.

Moser, C.O. (1989), 'Community participation in urban projects in the Third World', Progress in planning, 32, 71-133. 
Narayan, D., (2002), Bonds and bridges: social capital and poverty. Social capital and economic development: well-being in developing countries. Northampton, MA: Edward Elgar.

Nelson, N. and S. Wright (1995). 'Participation and power', in Nelson, N. and S. Wright (ed.), Power and Participatory Development: Theory and practice, London: Intermediate Technology Publications, pp. 1-18.

Nikkhah, H.A., and M. Redzuan, (2009). 'Participation as a medium of empowerment in community development', European Journal of Social Sciences, 11(1), 170-176.

Oakley, P., (1995). People's participation in development projects (Vol. 7). Intrac.

Pahl-Wostl, C. (2006), 'The importance of social learning in restoring the multifunctionality of rivers and floodplains', Ecology and Society, 11 (1): 10. http://www.ecologyandsociety.org/vol11/iss1/art10/, accessed 22 June 2016.

Parfitt, T. (2004). 'The Ambiguity of Participation: A Qualified Defence of Participatory Development', Third World Quarterly, 25(3), 537-556, http://www.jstor.org/stable/3993824, accessed 22 June 2016.

Pateman, C. (1970). Participation and Democratic Theory, Cambridge: Cambridge University Press.

Rahnema, M. (1992). 'Participation', in Sachs, W. (ed.), The Development Dictionary: a guide to knowledge as power, Zed Press, London, pp. 11631.

Reed. M., A.C. Evely, G. Cundill, I.R.A. Fazey, J. Glass, A. Laing, J. Newig, B. Parrish, C. Prell, C. Raymond and L. Stringer (2010), 'What is social learning?', Ecology and Society, http://www.ecologyandsociety.org/volXX/issYY/artZZ/, accessed 20 June 2016.

Richardson, A. (1983). Participation (Vol. 1). Routledge.

Sabatier, P.A, (1988), 'An Advocacy Coalition Framework of Policy Changes and the Role of Policy-Oriented Learning Therein', Policy Sciences, 21(2-3), 129-168.

Samah, A.A. and F, Aref (2009), 'People's Participation in Community Development: A Case Study in, a Planned Village Settlement in Malaysia', World Rural Observations, 1(2), 45-54.

Schneider, H. and M. Libercier (1995), 'Towards a New Partnership', in Schneider and Libercier (ed.), Participatory Development from advocacy to Action, Paris: OECD, pp. 1 7-28. 
Schuurman, F. (1993) 'Modernity, Post-modernity and the New Social Movements', in Schuurman, F. (ed), Beyond the Impasse: New Directions in Development Theory, Zed Books, London, pp. 187-206.

Stagl, S. 2007. 'Theoretical foundations of learning processes for sustainable development', International Journal of Sustainable Development and World Ecology, 14, 52-62.

Tufte, T. and P. Mefalopulos (2009). Participatory communication: A practical guide (No. 170). World Bank Publications.

Vygotsky, L. S. (1987). 'The collected works of LS Vygotsky: Vol. 1', in Problems of general psychology, RW Rieber \& AS Carton, (Ed.), N. Minick, trans.).

Waddington, M. and G. Mohan. (2004). 'Failing forward: going beyond PRA and imposed forms of participation', in S. Hickey and G. Mohan (Eds.) Participation: From Tyranny to Transformation? Exploring New Approaches to Participation in Development, London: ZED Books, 219245.

Watkins, C. and P. Mortimer (1999). 'Pedagogy: what do we know?', in Mortimer, P. (ed.), Understanding pedagogy and its impact on learning, London: Paul Chapman, pp. 20-45.

Webler, T., H. Kastenholz and O. Renn (1995), 'Public participation in impact assessment: a social learning perspective', Environmental impact assessment review, 15 (5), 443-463.

Welch, C. E., Jr. (1995). Protecting human rights in Africa: Strategies and roles of nongovernmental organizations, Philadelphia: University of Pennsylvania Press.

To cite this article:

Opaluwah, A. (2016). Participatory Development: A Tool of Pedagogy.

Exchanges: The Warwick Research Journal, 4(1), 120-139. Retrieved from:

http://exchanges.warwick.ac.uk/index.php/exchanges/article/view/120 